\title{
QUANTIFICATION OF ROAD VEHICLE PERFORMANCE PARAMETERS UNDER LABORATORY CONDITIONS
}

\author{
Branislav Šarkan' ${ }^{1}$ Ondrej Stopka ${ }^{2}$
}

1 University of Žilina, Faculty of Operation and Economics of Transport and Communications, Department of Road and Urban Transport, Univerzitná 1, 010 26, Žilina, Slovak Republic, e-mail: branislav.sarkan@fpedas. uniza.sk

2 Institute of Technology and Business in České Budějovice, Facultyof Technology, Department of Transport and Logistics, Okružní 517/10, 370 01, České Budějovice, Czech Republic, e-mail: stopka@mail.vstecb.cz

Received: 2018.04.20

Accepted: 2018.06.09

Published: 2018.09.01

\begin{abstract}
Engine performance of any kind of road vehicle is considered a fundamental parameter when selecting or comparing vehicles. It affects a number of operating characteristics including, for instance, vehicle maximum speed or vehicle acceleration. A vehicle manufacturer provides the data on performance in the technical description, however, engine performance value is specified in the vehicle registration certificate as well. Engine performance is indicated as the maximum engine output at certain engine speed. Thus, the vehicle operator disposes only the engine performance value, i.e. maximum value. In normal conditions of a road vehicle operation, several different situations take place when it is appropriate to verify the maximum engine performance value. The paper is focused on examination of the road vehicle performance, i.e. engine performance on the roller test bench and its detailed analysis.
\end{abstract}

Keywords: performance parameters, road vehicle, engine, roller test bench, examination.

\section{INTRODUCTION}

Engine performance, i.e. its characteristics depending on the engine speed, is considered to be the fundamental specified parameter. To examine the engine performance, there are several methods that are not equivalent to each other [18].

The basic methods for the engine performance examination may include $[7,9]$ :

- examination on engine brake,

- examination on roller test bench,

- dynamic examination through the vehicle acceleration.

Examination on roller test bench is carried out especially due to the operability of examination itself, because an engine is not removed from a vehicle during this test. However, the issue consists in detecting the actual engine performance on the crankshaft, since, during the test, perfor- mance at the periphery of the driving wheels is examined. The proper engine performance value is identified then with a subsequent correction.

Performance at the periphery of driving wheels is a significant indicator for objective assessment of the condition and properties of whole drive mechanism (powertrain) of a vehicle without any removal and with a minimum investment of working time. The value of performance at the periphery of driving wheels allows to find out the engine condition, i.e. if it needs repair or adjustment, or not. If a decrease in performance is detected, the engine malfunction is diagnosed using other diagnostic equipment. After malfunction removal, performed operation can be re-inspected on the test bench [7, 23, 27].

However, if the engine performance assessment needs to be done, the actual amount of losses for each type of vehicle or explicitly ex- 
pressed performance at the periphery of the driving wheels must be known. This performance has always a lower value when compared to the effective engine performance generated by an engine [27]. A lot of research studies related to similar issues were process, for example, in literature [5, $8,11,12,14,16,17,24,25]$.

Difference between the effective engine performance $\mathrm{P}_{\mathrm{ENG}}$ and performance at the wheels $\mathrm{P}_{\text {WHEEL }}$ represents the performance (power) drag $\mathrm{P}_{\mathrm{DRAG}}$. It is produced by the internal resistance of transmission (gearbox), final drive, friction of bearings of shafts and tire rolling resistance. The first three elements of the performance drag have about the same values. On the contrary, the tire rolling resistance increases with the vehicle speed, and also depends on the tire construction and pressure, as well as the load on driving axles and created conditions of a route (material of a surface of test rollers, their diameter and spacing) [23, 27].

\section{ROLLER TEST BENCH}

Engine performance, i.e. its characteristics depending on the engine speed, is considered to be the fundamental specified parameter. To examine the engine performance, there are several methods that are not equivalent to each other [18].

Roller test bench is a premium device intended for examination of an engine performance with inter-axle control regulation which is taken from the industrial laboratories. One roller on the tire allows to perform the long-term tests without the risk of tires damaging. During the examination, the vehicle is substantially higher from the laboratory floor and this fact allows for better flow of cooling air $[7,15]$.

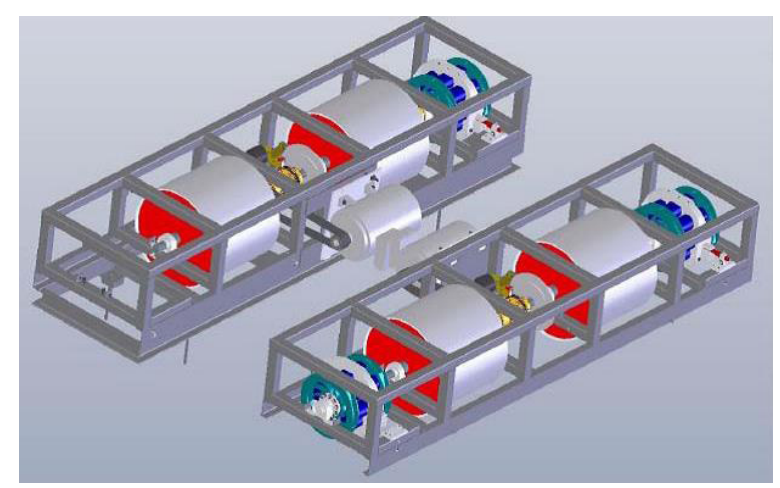

Fig. 1. Illustration of the roller test bench Maha MSR 1050 [15]
Table 1. Technical characteristics of Maha MSR 1050 [15]

\begin{tabular}{|c|c|}
\hline Rollers diameter & $762 \mathrm{~mm}$ \\
\hline Number of electric eddy-current brakes & 3 \\
\hline Number of electric engines & 2 \\
\hline Wheels gauge (min. - max.) & $900-2300 \mathrm{~mm}$ \\
\hline Measurable wheelbase & $1900-3500 \mathrm{~mm}$ \\
\hline Permissible axle load & $2500 \mathrm{~kg}$ \\
\hline Top speed & $320 \mathrm{~km} / \mathrm{h}$ \\
\hline Rotational roller unit weight & $700 \mathrm{~kg}$ \\
\hline Front axle wheel performance & $700 \mathrm{~kW}$ \\
\hline Rear axle wheel performance & $1400 \mathrm{~kW}$ \\
\hline Front axle tractive force & $8600 \mathrm{~N}$ \\
\hline Rear axle tractive force & $17200 \mathrm{~N}$ \\
\hline
\end{tabular}

Illustration of Maha MSR 1050 is vividly shown in Fig. 1.

Depending on a level, the following types of measurements can be carried out on this device [7, 15]: (1) engine performance examination (continuous, or discretely), (2) load simulation (constant tractive force, constant speed, simulation of drive, constant engine speed), (3) engine flexibility examination, (4) tachometer controlling.

Following table (Table 1) contains individual technical characteristics of Maha MSR 1050.

\section{RESULTS AND DISCUSSION}

During the continuous performance examination, maximum performance at the wheels, i.e. engine performance according to relevant legal regulations, and performance drag are detected. After selecting the continuous examination, a diagram which shows the actual measurement is displayed on the communication desk. As a first step, it is necessary to select a range of y-axis which shows the examined vehicle performance (performance at the wheels). It is selected depending on the value of vehicle maximum performance specified in a registration certificate, or in a technical manual about the vehicle in order that the performance curve is visible on the display during the whole examination.

The procedure of examination itself is based on continuous vehicle acceleration until the penultimate gear on which the examination runs. It must be reached to a speed of $50 \mathrm{~km} / \mathrm{h}$, since this value of vehicle speed activates the performance examination. At this moment, it is necessary to fully depress the accelerator pedal and monitor the communication panel display. After reaching 


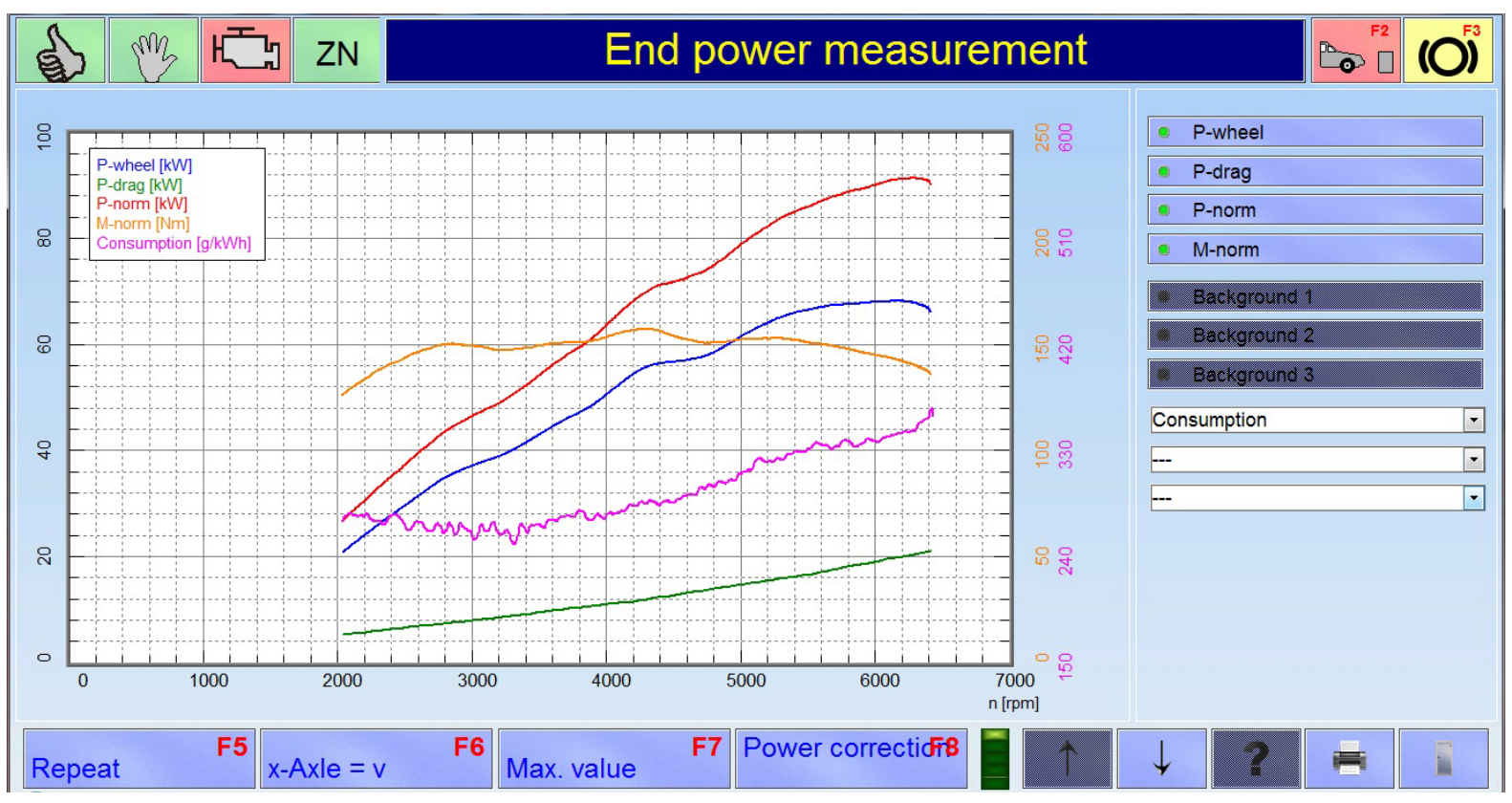

Fig. 2. Engine performance characteristics (measured in fourth gear)

the maximum performance, operator turns off the clutch by pressing the clutch pedal and releases the accelerator pedal. Deceleration phase is initiated which is characterized by analyzing the performance drag (transmission, final drive, tires). After accomplishing the performance examination, a graphical output of the engine performance according to the selected standard is appeared on a screen $[9,14]$.

\section{Analysis of the selected vehicle performance parameters}

In common practice of performance examination on roller test bench, vehicle performance characteristics at penultimate gear are recorded. From such an examination, basic data on a vehicle performance or engine can be obtained. This data include maximum engine performance (peak power) and maximum torque. In the case that a test bench is complemented by a fuel flow sen- sor, specific effective fuel consumption may be a part of the chart (see Fig. 2). Subsequently, this data can be compared with the data provided by a vehicle manufacturer $[7,25]$.

However, if examination of performance parameters is carried out at several gears, a number of data can be measured. It can be useful for detailed performance analysis of examined vehicle in whole engine speed (rpm) range. Following data analysis is carried out on the specific selected vehicle and its basic data declared by the manufacturer are listed in Table 2.

Maha MSF 1050 manufacturer specifies to measure the vehicle performance at penultimate gear. Of course, it is justified. Transition from minimum to maximum engine speed is sufficiently time consuming, and there is no wheel slip on rollers and vehicle does not reach the maximum design speed. Performance examination, especially at first gear, appears to be problematic. Examination takes place very quickly, relatively

Table 2. Basic technical parameters of the selected vehicle [2]

\begin{tabular}{|c|c|c|c|}
\hline Tradename & Kia Ceed & Engine code & G4FC \\
\hline Engine displacement & $1591 \mathrm{~cm}^{3}$ & Length & $4265 \mathrm{~cm}$ \\
\hline Fuel type & Petrol & Width & $1790 \mathrm{~cm}$ \\
\hline Number of cylinders & 4 & Height & $1480 \mathrm{~cm}$ \\
\hline Maximum performance & $90 \mathrm{~kW}$ at $6200 \mathrm{rpm}$ & Curb weight & $1163 \mathrm{~kg}$ \\
\hline Maximum torque & $154 \mathrm{Nm}$ at $4200 \mathrm{rpm}$ & Gross weight & $1710 \mathrm{~kg}$ \\
\hline Maximum design speed & $192 \mathrm{~km} \cdot \mathrm{h}^{-1}$ & & \\
\hline
\end{tabular}




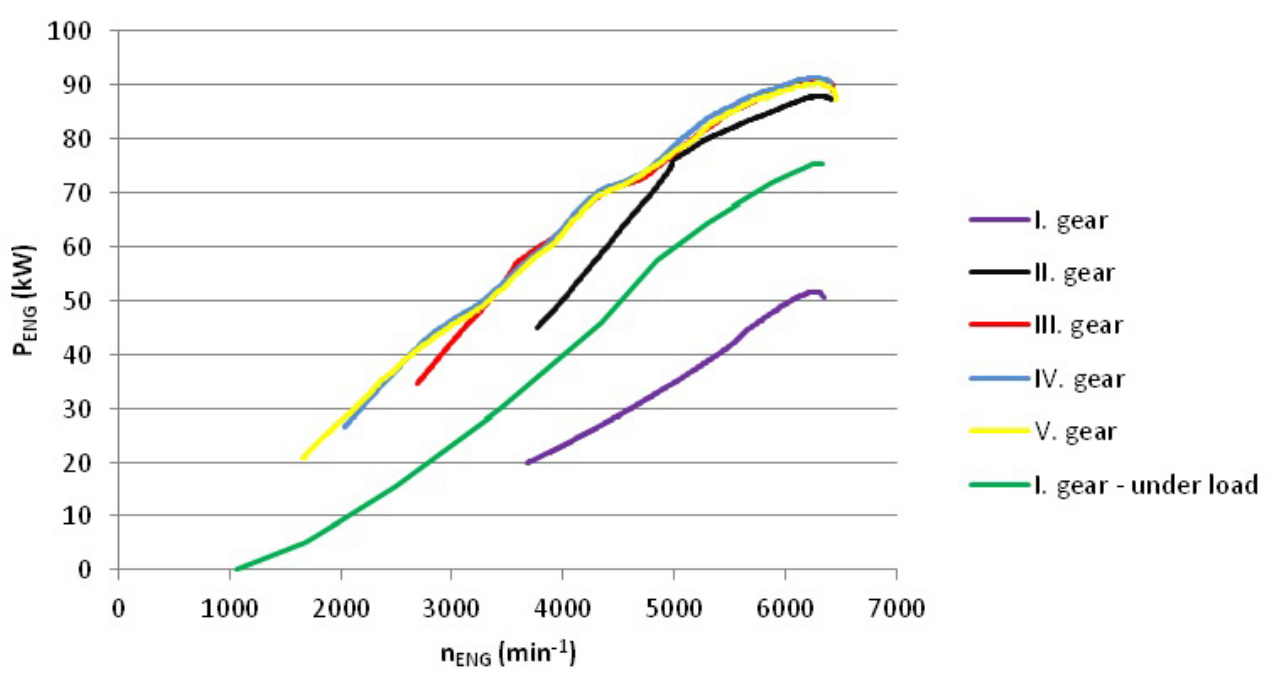

Fig. 3. Engine performance curves at each gear

large driving force is at the wheels, and in some cases, even engine control unit limits the maximum performance $[1,6,15]$.

Following Fig. 3 depicts the engine performance curves (rpm curves) measured on the roller test bench by a standard method, according to the test bench manufacturer's instructions [15]. The chart shows a justness of performance examination at the higher the gear. As for Kia Ceed, maximum performance examination at first gear seems to be problematic. During the performance examination process at this gear through the constant roller test bench load, the higher performance is already achieved (green curve), however, these values are not the maximum yet. From that reason, the following analysis evaluates only parameters at 2. -5 . gear. Since, the roller test bench alignment is in such a way that each examination is always launched at a speed of $50 \mathrm{~km} / \mathrm{h}$, thus with a higher gear, examination is launched at lower engine speed. In order to ensure the same engine speed range of engine performance curves for all gears, it is necessary to change the roller test bench alignment for each gear individually. This fact affects the range of further analyzed data as well.

Thus, Fig. 3 illustrates engine performance curves at individual gears depending on engine speed. Apparently, maximum performance similar to the manufacturer's specification should be achieved at each gear (except the first one) during the examination.

In Table 3, all the values (performance at the wheels - $\mathrm{P}_{\text {WHEEL }}$, performance drag - $\mathrm{P}_{\text {DRAG }}$, engine performance - $\mathrm{P}_{\mathrm{ENG}}$ and normalized performance - $\mathrm{P}_{\text {NORM }}$ ) recorded while maximum engine performance or normalized performance are processed in detail.

Normalized performance is engine performance, detected during the examination, calculated according to the applicable standard. In this case, calculations are performed according to the standard DIN 70 200. The detected engine performance $\left(\mathrm{P}_{\mathrm{ENG}}\right.$ ) is adjusted by a correction factor $\mathrm{K}_{\mathrm{A}}$ (see Equation 1) which guarantees relation of results to normalized environmental conditions [3, 22].

$$
K_{A}=\frac{1013}{p} \cdot\left(\frac{T}{293}\right)^{0.5}
$$

where: [p - atmospheric pressure on a test bench (mbar), T - air temperature on a test bench $\left.\left({ }^{\circ} \mathrm{K}\right)\right]$.

The following table (Tab. 3) includes a detailed overview of individual performance values detected during the performance examination.

In case of such performed examining and recording values of performance at the wheels, performance drag and engine performance, it is possible to analyze the operating characteristics at individual gears.

Performance drag $\mathrm{P}_{\text {DRAG }}$ is the power which is examined by a roller test bench after reaching the maximum performance at the wheels performing the so called deceleration test. During deceleration, appropriate gear remains used and power transfer to the wheels is interrupted by depressing the clutch pedal. This means that such a performance is recorded which needs to be overcome to rotate the spur 
Table 3. Detected performance parameters of Kia Ceed

\begin{tabular}{|c|c|c|c|c|c|c|c|}
\hline Gear & $\begin{array}{c}\mathbf{P}_{\text {NORM }} \\
{[\mathbf{k W}]}\end{array}$ & $\begin{array}{c}\mathbf{P}_{\text {ENG }} \\
{[\mathbf{k W}]}\end{array}$ & $\begin{array}{c}\mathbf{P}_{\text {WHEEL }} \\
{[\mathbf{k W}]}\end{array}$ & $\begin{array}{c}\mathbf{P}_{\text {DRAG }} \\
{[\mathbf{k W}]}\end{array}$ & $\begin{array}{c}\text { at } \mathbf{n}_{\text {ENG }} \\
\mathbf{r p m}\end{array}$ & $\begin{array}{c}\mathbf{T}_{\text {ENG }} \\
{[\mathbf{N m}]}\end{array}$ & $\begin{array}{c}\text { at } \mathbf{n}_{\text {ENG }} \\
\mathbf{r p m}\end{array}$ \\
\hline I & 51.5 & 49.5 & 41.7 & 7.8 & 6035 & 82.2 & 5955 \\
\hline II & 87.9 & 84.5 & 72.4 & 12 & 6275 & 146.5 & 4970 \\
\hline III & 90.9 & 87.3 & 72.4 & 14.9 & 6295 & 153 & 4290 \\
\hline IV & 91.9 & 87.7 & 67.7 & 20 & 6220 & 156.5 & 4205 \\
\hline $\mathrm{V}$ & 90.2 & 86.8 & 63.7 & 23.1 & 6295 & 153.4 & 4295 \\
\hline
\end{tabular}

$\mathrm{T}_{\mathrm{ENG}}$ - Engine torque

$\mathrm{n}_{\mathrm{ENG}}$ - Engine speed

rpm - revolutions per minute

Table 4. Values of performance at the periphery of driving wheels

\begin{tabular}{|c|c|c|c|c|c|c|c|c|c|}
\hline \multirow{2}{*}{ Gear } & \multicolumn{9}{|c|}{$\mathbf{P}_{\text {WHEEL }}[\mathbf{k W}$ at rpm } \\
\cline { 2 - 12 }$y$ & 2000 & 2500 & 3000 & 3500 & 4000 & 4500 & 5000 & 5500 & 6000 \\
\hline I & & & & & & & & & \\
\hline II & & & & & 40.9 & 51.8 & 63.8 & 68.2 & 71.2 \\
\hline III & & & 34.3 & 44.7 & 52.1 & 58.5 & 62.9 & 68.8 & 71.6 \\
\hline IV & & 29.4 & 36.9 & 42.8 & 50.3 & 56.5 & 61.3 & 66.3 & 67.8 \\
\hline V & 21.3 & 29.2 & 35.3 & 40.9 & 47.9 & 54.2 & 58.2 & 62.9 & 64.2 \\
\hline
\end{tabular}

Table 5. Performance drag values

\begin{tabular}{|c|c|c|c|c|c|c|c|c|c|}
\hline \multirow{2}{*}{ Gear } & \multicolumn{9}{|c|}{$\mathbf{P}_{\text {DRAG }}[\mathbf{k W}]$ at rpm } \\
\cline { 2 - 11 } & 2000 & 2500 & 3000 & 3500 & 4000 & 4500 & 5000 & 5500 & 6000 \\
\hline I & & & & & & & & & \\
\hline II & & & & & 7.2 & 8.3 & 9.4 & 10.4 & 11.4 \\
\hline III & & & 6.2 & 7.3 & 8.6 & 9.9 & 11.3 & 12.7 & 14.0 \\
\hline IV & & 6.3 & 7.6 & 9.2 & 10.7 & 12.3 & 14.4 & 16.2 & 18.7 \\
\hline V & 5.2 & 6.7 & 8.4 & 10.0 & 12.2 & 14.1 & 16.3 & 18.7 & 21.3 \\
\hline
\end{tabular}

gears in transmission and final drive system as well as the tire rolling on the rollers. Thus, it represents the sum of mechanical losses and rolling resistance $[9,14,21,27]$.

Table 3 contains the increasing performance drag with increasing gear at the same engine speed. This will ultimately result in a less available performance at the periphery of driving wheels.

The whole scale of recorded data of performance at the wheels $\left(\mathrm{P}_{\text {WHEEL }}\right)$ and performance $\operatorname{drag}\left(\mathrm{P}_{\text {DRAG }}\right)$ is processed in Tab. 4 and Tab. 5.

So far analyzed performance values depending on the engine speed declare the desired engine performance at the various gears. For the purpose of operating characteristics calculation, visual illustration of performance curves depending on the vehicle speed seems to be more useful. This is caused mainly for that reason that equivalent val- ues of driving resistance (aerodynamic resistance, acceleration resistance, etc.) can be assigned for each vehicle condition [4].

Fig. 4 depicts all the performances curves at each gear depending on the vehicle speed. From that characteristic, it is possible to read out very important operational vehicle states which are often calculated, using a theoretical calculation, with a relatively significant error.

The readable data from this characteristic includes [9, 14, 19]:

- maximum performance at the wheels depending on the vehicle speed,

- performance drag for individual gears,

- normalized performance,

- performance applicability to overcome the driving resistance,

- maximum vehicle speed. 


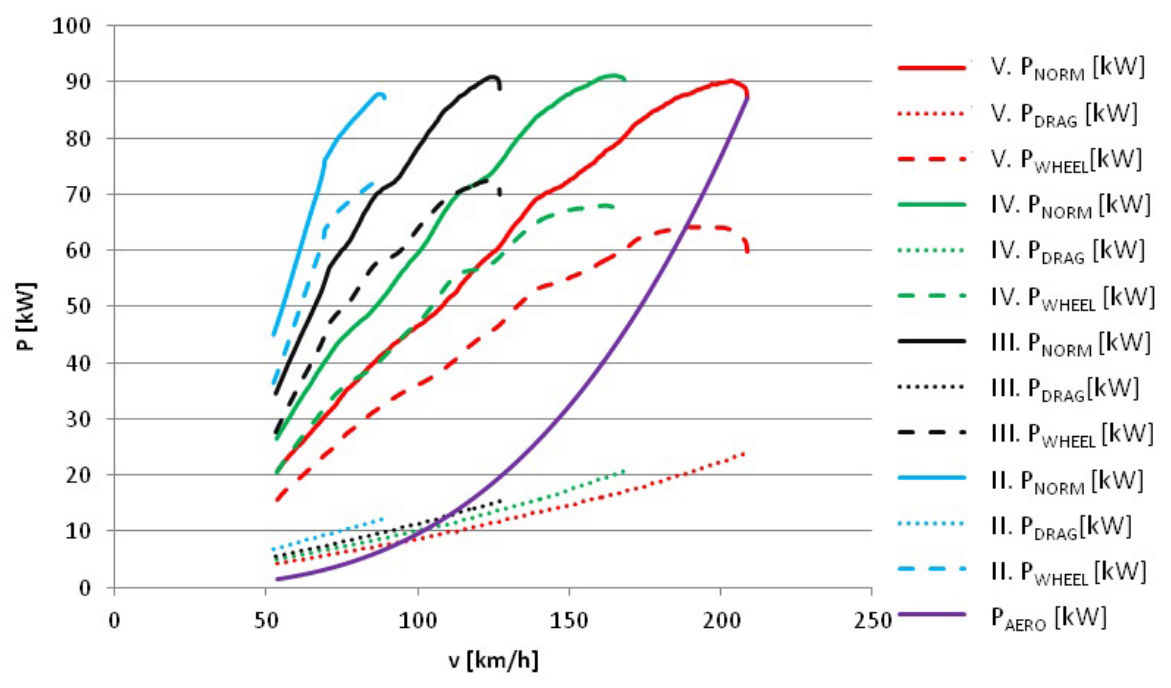

Fig. 4. Performances curves at individual gears, $\mathrm{P}_{\mathrm{AERO}}$ - Performance curve of aerodynamic resistance

\section{Maximum performance at the wheels depending on the vehicle speed}

With increasing vehicle speed, the maximum performance at the wheels decreases. This performance is applicable to overcome the driving resistance (it includes especially aerodynamic resistance, acceleration resistance, etc.) [4, 6].

\section{Performance drag for individual gears}

This performance represents the sum of mechanical losses in transmission and final drive system together with performance that is required to overcome the tire rolling resistance. From Fig. 4 , the increasing curve course of the performance drag depending on the vehicle driving speed can be seen. Examination of differences in performance drag values for individual gears at one point of the vehicle speed is an interesting measuring possibility. It represents increasing or decreasing losses among individual gears. Apparently, with increasing gear, the losses in transmission system decrease $[9,27]$.

\section{Performance applicability to overcome the driving resistance and specifying the maximum vehicle speed}

From the dependence of engine performance curves at various gears, it is possible to determine how much performance remains to overcome other components of driving resistance. After drawing the performance curve of aerodynamic resistance $\mathrm{P}_{\text {AERO }}$ (purple curve in Fig. 4 and is defined by the Eq. 2) in the whole range of vehicle speed, the value of remaining performances to overcome the driving resistance (e.g. gradient) at individual gears can be defined. Analysis is performed by comparing the performance at the wheels of particular gear and the sum of required performance to overcome the driving resistance $[4,20]$.

From the curves in following Fig. 5, it is possible to specify the maximum vehicle speed under a certain load, e.g. when driving uphill. Yellow curve defines the necessary performance to overcome aerodynamic resistance and gradient resistance when driving uphill with a $5^{\circ}$ inclination (gradient), which represents inclination of approximately $11 \%\left(\mathrm{P}_{\text {GRAD }}\right)[24,20]$.

Vehicle can get over such traffic operation at IV. gear with maximum speed of approx. 120 $\mathrm{km} / \mathrm{h}$. Vehicle maximum speed on a horizontal road without an inclination is determined from a curve $\mathrm{P}_{\text {AERO }}$ (see Eq. 2) and performance at the wheels of V. gear. Kia Ceed maximum speed identified in this type of examination is 188.35 $\mathrm{km} / \mathrm{h}[10,13,26]$.

$$
\boldsymbol{P}_{\text {AERO }}=\frac{1}{2} \cdot \rho_{\text {AERO }} \cdot \boldsymbol{c}_{\boldsymbol{x}} \cdot \boldsymbol{S} \cdot \boldsymbol{v}^{\mathbf{3}}(\mathrm{kW})
$$

where: $\left[\rho_{\text {AERO }}\right.$ - air density $\left(\mathrm{kg} \cdot \mathrm{m}^{-3}\right) ; \mathrm{c}_{\mathrm{x}}$ - aerodynamic resistance coefficient (-); S - vehicle frontal area $\left(\mathrm{m}^{2}\right), \mathrm{v}$ - vehicle speed $\left.\left(\mathrm{m} \cdot \mathrm{s}^{-1}\right)\right]$.

\section{CONCLUSIONS}

The manufacturer indicates basic parameters of a road vehicle for its future user. In most cases, 


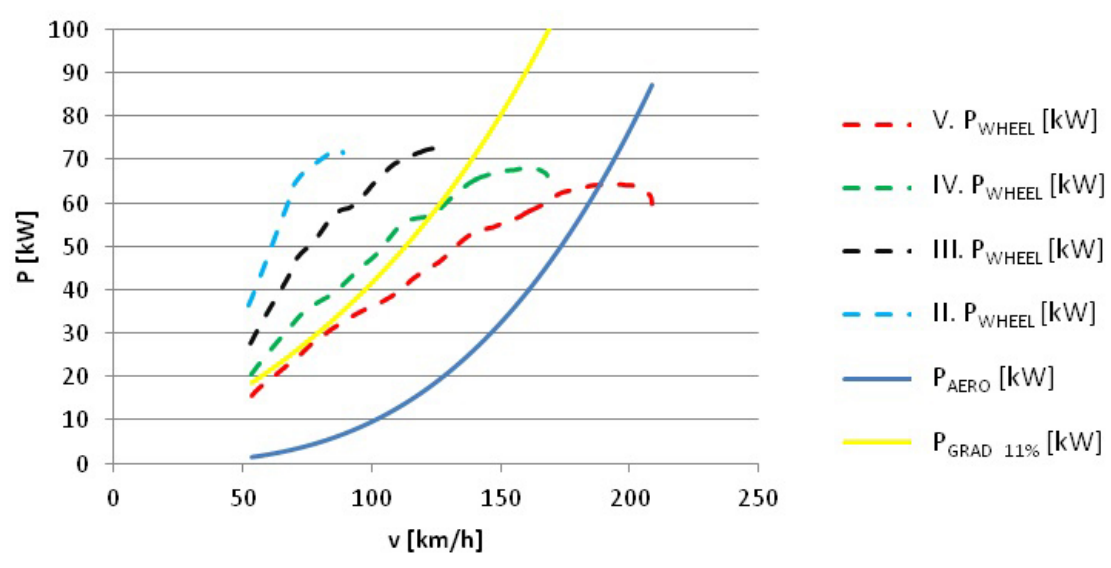

Fig. 5. Curves of performances at the wheels $\left(\mathrm{P}_{\text {WHEEL }}\right)$ and performance to overcome the driving resistance $\left(\mathrm{P}_{\mathrm{AERO}}\right)$

these include the data on maximum engine performance and engine torque, even possibly the gear ratios and fuel consumption according to the approval test. The paper analyzes in detail the vehicle performance parameters at each gear. Such data can be obtained by practical measurement (examination) of individual vehicle parameters on roller test bench. Especially, the fact that such data can be revealed only using the calculations, simplifications, or estimation of certain parameters, represents the significant advantage of such a type of examination.

On a specific case of examining the performance parameters of Kia Ceed, measurable and calculable parameters of particular road vehicle are demonstrated. These parameters include especially the performance curves at individual gears, performances achievable at the vehicle wheels, and thus, quantification of performance losses in transmission and final drive system at individual gears. It is also possible to quantify the maximum vehicle speed with respect to its actual performance or vehicle speed calculation for specific operating conditions (e.g. when driving uphill).

For future research issues, it would be useful to complement the final results with data obtained by the vehicle deceleration, thus, the actual parameters of the vehicle resistance (aerodynamic resistance and tire rolling resistance) could be detected.

\section{REFERENCES}

1. Bueno, A.V., Velásquez, J., Milanez, L.F.: A new engine indicating measurement procedure for combustion heat release analysis. In. Applied Thermal Engineering, Vol. 29/2009, Issue 8, pp. 1657-1675.
2. Cars Data - All technical specs in one car database. [online: http://www.cars-data.com/, access: 2017-01-15].

3. Chang, X., Rong, J., Zhou, C.J., Li, H.J.: Relationship between Driver's Feeling and Vehicle Operating Characteristics on Urban Road. In. 12th World Congress on Intelligent Control and Automation (WCICA), Guilin, Peoples Republic of China, 2016, pp. 3033-3037.

4. Cheng, S.Y., Mansor, S.: Influence of rear-roof spoiler on the aerodynamic performance of hatchback vehicle. In. MATEC Web of Conferences, 2nd International Conference on Automotive Innovation and Green Vehicle (AiGEV), Malaysia Automot Inst, Cyberjaya, Malaysia, Vol. 90/2017, No. UNSP 01027. DOI:10.1051/matecconf/20179001027.

5. Collette, C.: Importance of the wheel vertical dynamics in the squeal noise mechanism on a scaled test bench. In. Shock and Vibration, Vol. 19/2012, Issue 2, pp. 141-149. DOI:10.3233/SAV-2011-0620.

6. Droździel, P., Krzywonos, L.: The estimation of the reliability of the first daily diesel engine start-up during its operation in the vehicle. In. Eksploatacja i Niezawodnosc - Maintenance and Reliability, Vol. 41/2009, Issue 1, pp. 4-10.

7. Fernandez-Yaneza, P., Armasa, O., MartinezMartinez, S.: Impact of relative position vehiclewind blower in a roller test bench under climatic chamber. In. Applied Thermal Engineering, Vol. 106/2016, pp. 266-274. DOI:10.1016/j.applthermaleng.2016.06.021.

8. Gerlici, J., Lack, T.: Rail vehicles brake components test bench utilisation. In. Applied Mechanics and Materials, Vol. 486/2014, pp. 379-386. In. 51 st Annual of the International Scientific Conference on Experimental Stress Analysis, Litoměřice, Czech Republic, 2013. DOI:10.4028/www.scientific.net/AMM.486.379. 
9. James, D.J.G., Burnham, K.J., Richardson, M.J., Williams, R.A.: Improving vehicle performance using adaptive control techniques. In. Artificial Life and Robotics, Vol. 3/1999, Issue 4, pp. 236241. DOI:10.1007/BF02481187.

10. Jedlinski, L., Caban, J., Krzywonos, L., Wierzbicki, S., Brumercík, F.: Application of the vibration signal in the diagnosis of the valve clearance of an internal combustion engine. In. Vibroengineering Procedia, Vol. 3/2014, pp. 14-19.

11. Kim, M.S.: Study on the adhesion characteristic between wheel and rail using the scaled testbench. In. International Journal of Mechanics, Vol. 9/2015, pp. 198-205. [online: http://www.naun. org/main/NAUN/mechanics/2015/a462003-149. pdf, access: 2016-10-05].

12. Lakatos, I., Pup, D., Czeglédi, D.: Determination of power and torque curves of electric driven vehicles based on diagnostic methods. In. Proceedings of the ASME Design Engineering Technical Conference, International Design Engineering Technical Conferences and Computers and Information in Engineering Conference, IDETC/CIE 2015, Boston, United States, V009T07A069, 2015, 11 p. DOI:10.1115/DETC2015-46724.

13. Lingaitis, L.P., Lebedevas, S., Liudvinavičius, L.: Evaluation of the operational reliability and forecasting of the operating life of the power train of the freight diesel locomotive fleet. In. Eksploatacja i Niezawodnosc - Maintenance and Reliability, Vol. 16/2014, Issue 1, pp. 73-79.

14. Luo, Q.G., Zhang, Y.F., Zhang, G.Y., Wu, D.M.: The measurement of performance parameters in road test of tracked vehicles. In. 6th International Symposium on Test and Measurement (ISTM), Vol. 1-9/2005, pp. 4826-4829.

15. Maha MSR - Technical data. [online: http://www. maha.de/single-roller-dynamometer-msr-1000. htm/, access: 2016-12-10].

16. Moon, H., Chellappa, R., Rosenfeld, A.: Performance analysis of a simple vehicle detection algorithm. In. Image and Vision Computing, Vol. 20/2002, Issue 1, pp. 1-13. DOI:10.1016/S02628856(01)00059-2.

17. Ochieng, W.Y., Sauer, K.: Urban road transport navigation: performance of the global positioning system after selective availability. In. Transportation Research Part C - Emerging Technologies, Vol. 10/2002, Issue 3, pp. 171-187. DOI:10.1016/ S0968-090X(02)00008-6.

18. Papoušek, M., Štěrba, P.: Diagnostika spalovacích motorů. 2nd ed. Computer Press, Brno, Czech Republic, 2007. $223 \mathrm{p}$.
19. Palella, N., Colombo, L., Pisoni, F., Avellone, G., Philippe, J.: Sensor Fusion for Land Vehicle Slope Estimation. In. 10th International Conference on DGON Inertial Sensors and Systems (ISS), Karlsruhe, Germany, 2016. 20 p. DOI:10.1109/InertialSensors.2016.7745683.

20. Parczewski, K.: Effect of tyre inflation pressure on the vehicle dynamics during braking maneuver. In. Eksploatacja i Niezawodnosc - Maintenance and Reliability, Vol. 15/2013, Issue 2, pp. 134-139.

21. Phlips, P.: Analytic Model of Powertrain Drive Cycle Efficiency, with Application to the US New Vehicle Fleet. In. SAE International Journal of Fuels and Lubricants, Vol. 9/2016, Issue 1, pp. 269-289. DOI:10.4271/2016-01-0902.

22. Resitoglu, I.A., Altinisik, K., Keskin, A.: The pollutant emissions from diesel-engine vehicles and exhaust after treatment systems. In. Clean Technologies and Environmental Policy, Vol. 17/2015, Issue 1, pp. 15-27. DOI:10.1007/ s10098-014-0793-9.

23. Schifter, I., Gonzalez, U., Diaz, L., Gonzalez-Macias, C., Mejia-Centeno, I.: Experimental and vehicle (on road) test investigations of spark-ignited engine performance and emissions using high concentration of MTBE as oxygenated additive. In. Fuel, Vol. 187/2017, pp. 276-284. DOI:10.1016/j. fuel.2016.09.044.

24. Vong, C., Wong, P., Lia, Y.: Prediction of automotive engine power and torque using least squares support vector machines and Bayesian inference. In. Engineering Applications of Artificial Intelligence, Vol. 19/2006, Issue 3, pp. 277-287. DOI:10.1016/j.engappai.2005.09.001.

25.Xu, G., Su, J., Chen, R., Pan, H., Zhang, L., Wang, X.: Measurement performance assessment: Dynamic calibration compared with static calibration method for roller tester of vehicle brake force. In. Advances in Mechanical Engineering, Article ID162435, 2014, 8 p. DOI:10.1155/2014/162435.

26. Zhao, K., Liu, Y., Huang, X., Yang, R., Wei, J.: Uninterrupted shift transmission and its shift characteristics. In. IEEE/ASME Transactions on Mechatronics, Vol. 19/2014, Issue 1, pp. 374-383. DOI:10.1109/TMECH.2012.2235183.

27. Zhao, J., Zhang, J., Zhu, B.: Coordinative traction control of vehicles based on identification of the tire-road friction coefficient. In. Proceedings of the Institution of Mechanical Engineers, Part D: Journal of Automobile Engineering, Vol. 230/2015, Issue 12, pp. 1585-1604. DOI:10.1177/0954407015618041. 